\title{
Korelasi Kegiatan Ekstrakurikuler Seni Kaligrafi Dengan Bakat Seni Rupa Siswa MI Miftahul Huda Tanjunganom Diwek Jombang
}

\author{
${ }^{1}$ Vian Hanes Andreastya, ${ }^{2}$ Iqbal Fidi Almuhtadin \\ ${ }^{1}$ Universitas Hasyim Asy'ari Tebuireng ${ }^{2}$ Kementerian Agama Kab. Jombang \\ ${ }^{1}$ Email: iqbalfidi@gmail.com
}

\begin{abstract}
Abstrak
Kegiatan ekstrakurikuler seni kaligrafi merupakan serangkaian program kegiatan belajar mengajar yang fokus pada pelatihan dan pengembangan tentang seni kaligrafi. Sedangkan bakat merupakan sebuah potensi tersembunyi bawaan dari lahir yang perlu dilakukan latihan dan pengembangan, dengan adanya bakat maka siswa akan mudah serta lebih cepat dalam memahami apa yang dipelajari. Usia anak sekolah dasar merupakan usia perkembangan, yang mana pihak sekolah harus memperkenalkan suatu kegiatan yang dapat memunculkan minat bakat setiap individu siswa, hal tersebut sesuai dengan pendapat Ulin Nuha yang menyatakan "tidak semua orang mampu menguasai khat/kaligrafi dengan baik, karena kemampuan tersebut sangat erat kaitannya dengan bakat yang dimiliki oleh masing-masing individu".

Penelitian ini dilakukan untuk (1) mendeskripsikan bagaimana pelaksanaan kegiatan ekstrakurikuler seni kaligrafi di MI Miftahul Huda Tanjunganom. (2) mendeskripsikan bakat seni rupa siswa MI Miftahul Huda Tanjunganom. (3) mendeskripsikan korelasi kegiatan ekstrakurikuler seni kaligrafi dengan bakat seni rupa siswa MI Miftahul Huda Tanjunganom. Penelitian ini menggunakan desain penelitian Expostfacto. Populasi yang digunakan dalam penelitian ini adalah seluruh siswa kelas 3,4 dan 5 MI Miftahul Huda dan teknik pengambilan sampelnya menggunakan Stratified Random Sampling. Sampel penelitian ini adalah siswa kelas 3, 4 dan 5 dimana pada setiap kelas akan diambil sebanyak 10 siswa untuk dijadikan sebagai sampel penelitian, sehingga diharapkan mampu mewakili jumlah populasi.

Teknik pengumpulan data menggunakan angket, observasi dan dokumentasi. Teknik analisis data yang digunakan untuk menguji hipotesis menggunakan teknik korelasi Spearman Rank. Setelah dilakukan analisis hubungan maka dapat diketahui nilai Sig 0,046 $\leq 0,05$ sehingga H0 ditolak dan Ha diterima, maka dari itu dapat disimpulkan bahwa terdapat hubungan antara variabel $X$ dengan variabel $Y$. Kemudian dari $\mathrm{R}$ (koefisien korelasi) bernilai 0,366 (positif), maka korelasi antara $X$ dengan $Y$ termasuk jenis korelasi positif (sebanding).
\end{abstract}

Kata kunci: Ekstrakurikuler Seni Kaligrafi, Bakat Seni Rupa 


\section{PENDAHULUAN}

Dalam UU No 20 Tahun 2003 Tentang Sistem Pendidikan Nasional pada Pasal 3, yang menyebutkan bahwa pendidikan nasional berfungsi mengembangkan kemampuan dan membentuk karakter serta peradaban bangsa yang bermartabat dalam rangka mencerdaskan kehidupan bangsa, bertujuan untuk mengembangkan potensi peserta didik agar menjadi manusia yang beriman dan bertakwa kepada Tuhan yang Maha Esa, berakhlaq mulia, sehat, kreatif, mandiri dan menjadi warga negara yang demokratis serta bertanggungjawab. ${ }^{1}$

Pemerataan pendidikan dan pencapaian mutu yang baik menjadikan warga Negara Indonesia memiliki ketrampilan hidup (life skill) sehingga mampu untuk mengenal dan mengatasi masalah diri dan lingkungannya, serta mendorong berdirinya masyarakat madani dan modern yang dijiwai dengan nilai-nilai Pancasila. ${ }^{2}$

Dewasa ini, dunia pendidikan di sekolah khususnya, menghadapi berbagai macam tuntutan yang sangatbesar, karena bukan hanya sebatas mendidik tetapi juga harus mampu membentuk mindset peserta didiknya sesuai dengan perkembangan zaman yang sangat pesat ini, sehingga diharapkan para generasi manusia ini menjadi SDM yang baik dan dapat bertanggungjawab.

Peran orang tua dalam mengembangkan bakat minat anaknya sebenarnya merupakan sebuah keharusan, karena hal itu merupakan sikap kepedulian orang tua terhadap masa depan seorang anak. Salah satu cara yang baik adalah memfasilitasi anaknya untuk menggali serta mengembangkan bakatnya, misalnya dengan mengikutkan anaknya ke lembaga kursus atau tempat latihan khusus untuk sepak bola, menari,

\footnotetext{
${ }^{1}$ Imam Muslih \& Jazilatul Maghfiroh, Pengaruh Penggunaan Media Visual dan Model Pembelajaran Cooperative Jigsaw Terhadap Hasil Belajar. Jurnal Alta'dib vol 7 no.1 hlm: 2.

${ }^{2}$ http//:Pewarisilmu2016.blogspot.com/2016/ 10/Ekstrakurikuler Dalam Implementasi Kurikulum 2013. diakses tgl 13-10-2018.
} 
bernyanyi, melukis dan lain sebagainya. Maka dari itu, lembaga sekolah juga harus memberikan kontribusi yang lebih baik dengan mengadakan kegiatan- kegiatan yang dapat memfasilitasi kebutuhan peserta didik yang sesuai dengan minat masing-masing.

Sekolah merupakan lembaga pendidikan yang menampung peserta didik dengan latar belakang dan tingkat intelegensi yang berbeda- beda untuk diberikan bimbingan agar mereka memiliki kemampuan, kecerdasan dan keterampilan. Setiap sekolah harus berusaha menyeimbangkan antara pengembangan kecerdasan intelektual dan pengembangan aspek kepribadian lainnya.

Pada kenyataannya memang bahwa bakat, minat dan kreativitas merupakan salah satu faktor yang sangat penting diperhatikan oleh setiap guru dalam mengajar di sekolah, guna untuk mencapai pelaksanaan tujuan pendidikan di sekolah secara baik. Apabila faktor ini diabaikan begitu saja, biasanya akan membawa pengaruh sulitnya untuk mencapai hasil pelaksanaan pendidikan secara optimal. Bahkan bakat, minat dan kreativitas termasuk sebagai suatu komponen untuk pencapaian mutu proses belajar dan mengajar bagi setiap guru di sekolah. Dan solusi terbaiknya adalah melalui ekstrakurikuler yang diminati siswa untuk mengembangkan bakatnya. ${ }^{3}$

Secara umum, kegiatan ekstrakurikuler di sekolah memiliki nilai tambah yang diberikan siswa sebagaipenunjang dalam belajar, dimana hal tersebut sebagai wujud manifestasi sarana penting dalam meningkatkan dan menopang tercapainya visi misi pembangunan yang dilakukan di luar jadwal akademis sekolah, sehingga dapat menumbuhkan semangat siswa dalam meningkatkan prestasinya, baik di bidang akademik maupun non akademik.

Salah satu kegiatan dari ekstrakurikuler yang dilakukan tersebut

${ }^{3}$ Siti Mariah Ulfah, Seni kaligrafi Sebagai Salah Satu Media Pembelajaran Agama Islam, Jurnal Pendidikan (At-Ta'lim); Vol. 4, 2013. 
adalah kegiatan ekstrakurikuler seni kaligrafi Islam yang di dalamnya siswa tidak hanya belajar tentang seni tulis menulis arab tetapi juga belajar tentang ilmu estetika seni rupa dalam mengasah dan memfungsikan otak kanan dan juga melatih kesabaran dan keuletan siswa selama berproses, sehingga dapat memunculkan dan mengembangkan bakat keterampilan seni sejak usia perkembangan.

Berdasarkan pada penelitian terdahulu, seni kaligrafi sebagai media pembelajaran agama Islam memang harus diaplikasikan, karena pembelajaran agama islam sebagai dasar kehidupan umat islam harus ditanamkan sejak dini. Dalam kegiatan belajar mengajar kaligrafi khususnya anak-anak usia dasar seperti Madrasah Ibtidaiyah hendaknya diterapkan secara maksimal dengan beberapa metode yang dianggap sesuai dengan materi pelajaran agama yang tidak hanya dibidang tulisan tetapi juga bidang wawasan seni Islam.

Dengan adanya kegiatan ekstrakurikuler seni kaligrafi di MI Miftahul Huda yang dijadikan sebagai pelajaran muatan lokal pada kelas tertentu yang sifat pembelajarannya berjenjang, sehingga dapat harapankan mampu menjadi salah satu sarana dalam mengembangkan bakat peserta didik disekolah. Akan tetapi dari sekian banyak siswa kelas 3, 4 dan 5 masih sangat sedikit yang mampu menguasai seni kaligrafi dengan baik, sehingga masih banyak siswa yang belum mampu menguasai hal tersebut.

Maka dari itu, berdasarkan uraian di atas mendorong peneliti untuk mengadakan penelitian lebih mendalam yang berjudul "Korelasi Kegiatan Ekstrakurikuler Seni Kaligrafi Terhadap Pengembangan Bakat Seni Rupa Siswa Madrasah Ibtidaiyah Miftahul Huda Tanjunganom Diwek Jombang". 


\section{Hipotesis Penelitian}

Hipotesis penelitian ada yang menyatakan tidak adanya hubungan atau pengaruh antara variabel dengan variabel yang lain, hipotesis ini dinamakan Hipotesis nol (H0), ada juga hipotesis yang menyatakan adanya hubungan atau pengaruh antara variabel dengan variabel yang lain, hipotesis seperti ini disebut dengan Hipotesis alternatif (Ha). ${ }^{4}$

Adapun hipotesis yang peneliti ajukan dalam penelitian ini adalah:

1. Hipotesis nol (H0) Dalam hipotesis nol ini dinyatakan "tidak terdapat pengaruh ekstrakurikuler kaligrafi terhadap perkembangan bakat seni rupa siswa MI Miftahul Huda Tanjunganom Diwek Jombang ”.

2. Hipotesis alternatif (Ha)

Dalam hipotesis alternatif ini dinyatakan "terdapat pengaruh ekstrakurikuler kaligrafi terhadap perkembangan bakat seni rupa siswa MI Miftahul Huda Tanjunganom Diwek Jombang ”.Secara umum, khat adalah seni penulisan huruf- huruf arab, baik berdiri sendiri maupun tersusun dengan yang lainnya dengan baik dan indah, serta sesuai dengan pokok dan aturan yang ditetapkan oleh para pakar yang ahli dalam seni khat. Kaligrafi (khat), disebut juga tahsinul khat (membaguskan tulisan), merupakan kategori menulis yang tidak hanya menekankan rupa atau postur huruf dalam membentuk kata- kata atau kalimat, tetapi juga menyentuh aspek- aspek estetika (al-jamal). ${ }^{5}$

Pembelajaran kaligrafi memiliki tujuan menumbuh kembangkan potensi, sikap dan ketrampilan. Untuk taman kanak-kanak (TK) sampai siswa sekolah dasar (SD) atau Madrsah Ibtidaiyah (MI) cukup dengan kegiatan mewarnai kaligrafi atau menggambar kaligrafi yang tujuannya diarahkan kepada sarana pengenalan, yang nantinya diharapkan dapat memancing minat siswa untuk mempelajarinya.

Pada dasarnya mempelajari seni khat atau kaligrafi membutuhkan

\footnotetext{
${ }^{4}$ Nurul Zuriah, Metodologi Penelitian Sosial dan Pendidikan, (Jakarta: PT Bumi Aksara, 2007), hlm: 163.

${ }^{5}$ Ulin Nuha, Ragam Metodologi \& Media Pembelajaran Bahasa Arab , (Yogyakarta: DIVA Press, 2016), hlm: 116.
} 
waktu yang tidak singkat, karena memiliki tingkat kesulitan tersendiri yang terdapat pada setiap cara penulisan huruf hijaiyah berdasarkan macam jenis khat. Sehingga tidak banyak orang yang memiliki pemahaman yang mendalam terhadap disiplin ilmu Khat/ kaligrafi. Menurut Ulin Nuha "tidak semua orang mampu menguasai khat dengan baik. Karena kemampuan dalam menguasai khat juga sangat erat kaitannya dengan bakat yang dimiliki oleh masing- masing individu". 6

Bakat (aptitude) mengandung makna kemampuan bawaan yang merupakan potensi (potensial ability) yang masih perlu pengembangan dan pelatihan lebih lanjut karena sifatnya masih bersifat potensial. Menurut Utami Munandar, bakat merupakan potensi yang masih memerlukan ikhtiar pengembangan dan pelatihan secara serius dan sistematis agar dapat terwujud. Bakat berbeda dengan kemampuan (ability) yang memiliki makna daya untuk melakukan sesuatu, sebagai hasil pembawaan dan latihan. Sedangkan kemampuan dapat dikembangakan di masa yang akan datang apabila latihan dilakukan secara optimal, yang terkadang menghabiskan lebih banyak waktu dalam prosesnya.

Setiap orang memiliki kemampuan yang berbeda sesuai dengan potensi yang ada pada dirinya. Potensi yang dimiliki individu ada yang bersifat umum dan ada yang khusus.

\section{METODE PENELITIAN}

Penelitian ini termasuk penelitian kuantitatif dengan design Expost facto yang merupakan penelitian dimana variabel-variabel bebas telah terjadi ketika peneliti mulai dengan pengamatan variabel terikat dalam suatu penelitian. Keterikatan antara variable bebas dengan variabel terikat sudah terjadi secara alami. Dari hal tersebut, peneliti ingin melacak kembali apa yang menjadi faktor penyebabnya.

Bila ditinjau dari macam-macam jenis penelitian Expost facto,

${ }^{6}$ Sukardi, Metodologi Penelitian Pendidikan, (Jakarta: PT Bumi Aksara, cetakan ke-7 2009), hal: 165 
maka penelitian ini termasuk penelitian korelasi (hubungan), yang digunakan untuk menganalisis dua variabel yang saling mempengaruhi, sehingga terjadi hubungan sebab akibat yang signifikan. Dan sampelnya diambil secara random, sehingga dapat mewakili populasi yang ditentukan. Maka obyek populasi penelitian ini adalah seluruh siswa kelas 3, 4 dan 5 MI Miftahul Huda.

Sehingga data dikumpulkan melalui penyebaran angket yang hasilnya dianalis dengan teknik korelasi Spearman Rank, yang gunanya untuk mencari nilai korelasi antara variabel $X$ dengan variabel $Y$. Yang dihitung menggunakan aplikasi SPSS.

\section{PEMBAHASAN}

Setelah diadakan penelitian di MI Miftahul Huda Tanjunganom Diwek Jombang yang bertujuan untuk mengetahui bagaimana hubungan ekstrakurikuler seni kaligrafi dengan bakat seni rupa, maka data yang disajikanini berupa data yang diperoleh melalui penyebaran angket yang telah disebarkan kepada siswa dan siswi kelas 3, 4 dan 5 yang terpilih sebagai responden dengan jumlah 30 siswa.

Untuk mengetahui ada atau tidaknya korelasi antara variabel $X$ (ekstrakurikuler seni kaligrafi) dengan variabel $Y$ (bakat seni rupa siswa), peneliti menggunakan hasil instrumen angket dalam analisisnya. Maka dari itu sebelum diuji hipotesis menggunakan uji spearman rank maka perlu didahului dengan uji validitas dan uji reliabilitas pada angket tersebut yang akan disajikan sebagai berikut: 
Tabel 2: Hasil Uji Validitas Variabel $X$

\begin{tabular}{|c|c|c|c|}
\hline NO & $\begin{array}{l}\text { BUTIR } \\
\text { INSTRUMEN }\end{array}$ & SIG & KET \\
\hline 1 & 1 & 0,018 & Val1d \\
\hline 2 & 2 & 0,001 & Valid \\
\hline 3 & 3 & 0,001 & Valid \\
\hline 4 & 4 & 0,044 & Valid \\
\hline 5 & 5 & 0,008 & Valid \\
\hline 6 & 6 & 0,028 & Valid \\
\hline 7 & 7 & 0,011 & Valid \\
\hline 8 & 8 & 0,004 & Valid \\
\hline प9 & y & 0,005 & Val1d \\
\hline 10 & 10 & 0,005 & Valid \\
\hline П1 & П1 & 0,002 & Valid \\
\hline $\mathrm{TL}$ & $\mathrm{TL}$ & 0,029 & Valid \\
\hline 13 & 13 & 0,001 & Valid \\
\hline 14 & 14 & 0,001 & Valid \\
\hline 15 & 15 & 0,011 & Valid \\
\hline
\end{tabular}

Dari table di atas dapat diketahui bahwa setiap butir angket dinyatakan valid, karena nilai sig- 2 tailed $<0.05$. Adapun hasil uji reliabilitas angket yang telah dihitung menggunakan SPSS versi 22 dapat diketahui pada tabel berikut ini:

\section{Reliability Statistics}

\begin{tabular}{|c|c|}
\hline Cronbach's Alpha $^{\mathrm{a}}$ & N of Items \\
\hline 658 & 15 \\
\hline
\end{tabular}

Dari tabel hasil uji reliabilitas di atas dapat diketahui bahwa nilai Cronbach's Alpha $0.658>0.6$, maka dapat dikatakan bahwa angket pada variabel $X$ telah reliabel. Karena suatu instrumen dianggap reliabel jika nilai Cronbach's Alpha $>0.6$.

Selanjutnya tabel 3: Hasil Uji Validitas Variabel $Y$

\begin{tabular}{|c|c|c|c|}
\hline NO & $\begin{array}{l}\text { BUTSTR } \\
\text { INSTRUMEN }\end{array}$ & SIG & KET \\
\hline 1 & 1 & 0,009 & Val1d \\
\hline 2 & 2 & 0,005 & Valid \\
\hline 3 & 3 & 0,024 & Valid \\
\hline 4 & 4 & 0,014 & Valid \\
\hline 5 & 5 & 0,033 & Valid \\
\hline 6 & 6 & 0,041 & Valld \\
\hline 7 & 7 & 0,023 & Valid \\
\hline 8 & 8 & 0,030 & Valld \\
\hline y & 9 & 0,049 & Valid \\
\hline 10 & 10 & 0,022 & Val1d \\
\hline 11 & II & 0,020 & Valld \\
\hline 12 & 12 & 0,023 & Valid \\
\hline 13 & 13 & U,005 & Valid \\
\hline 14 & 14 & 0,001 & Valid \\
\hline 15 & 15 & 0,016 & Valid \\
\hline
\end{tabular}


Dari table di atas dapat diketahui bahwa setiap butir angket dinyatakan valid karena nilai sig-2 tailed $<0.05$. Adapun hasil uji reliabilitas angket dapat diketahui pada tabel berikut ini:

\begin{tabular}{|c|c|}
\multicolumn{2}{|c|}{ Reliability Statistics } \\
$\begin{array}{c}\text { Cronbach's } \\
\text { Alpha }\end{array}$ & N of Items \\
\hline 690 & 15 \\
\hline
\end{tabular}

Dari tabel hasil uji reliabilitas di atas dapat diketahui bahwa nilai Cronbach's Alpha $0.690>0.6$, maka dapat dikatakan bahwa angket pada variabel $Y$ telah reliabel. Adapun hasil analisa korelasi antara dua variabel dari hasil output SPSS dapat dilihat pada tabel di bawah ini: Tabel 4: Hasil Uji Korelasi Spearman Rank

Correlations

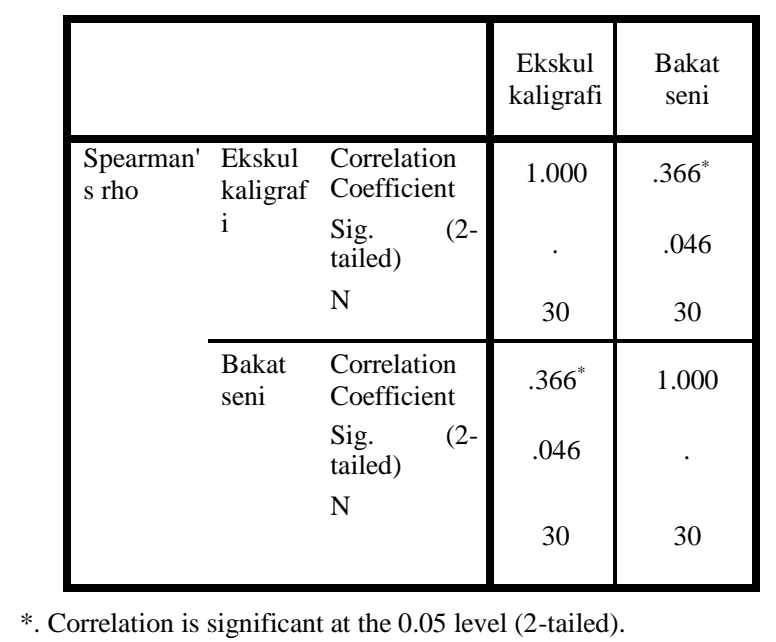

Pada tabel 4.10 di atas dapat diketahui nilai Sig 0,046 $\leq 0,05$ sehingga H0 ditolak dan Ha diterima, maka dari itu dapat disimpulkan bahwa terdapat hubungan antara variabel $X$ dengan variabel $Y$. Kemudian dari $\mathrm{R}$ (koefisien korelasi) bernilai 0,366 (positif), maka korelasi antara $X$ dengan $Y$ termasuk jenis korelasi positif (sebanding). 


\section{KESIMPULAN}

1. Berdasarkan hasil analisis data yang diperoleh dari hasil penelitian menunjukkan bahwa pelaksanaan ekstrakurikuler kaligrafi di MI Miftahul Huda Tanjunganom Diwek Jombang memiliki nilai yang signifikan, karena hal ini berdasarkan sikap antusiasme siswa siswi yang cukup tinggi pada mapel seni kaligrafi tersebut.

2. Hasil penelitian menunjukkan bahwa bakat seni rupa siswa MI Miftahul Huda kurang signifikan, hal ini berdasarkan hasil observasi peneliti di kelas, dimana siswa yang mampu menulis kaligrafi dengan baik hanya $30 \%$ dari jumlah keseluruhan, yang artinya hanya siswa berbakat yang mampu menulis kaligrafi dengan baik.

3. Korelasi antara variabel $X$ dengan variabel $Y$ berdasarkan hasil analisis data dan pembahasan penelitian, maka dapat disimpulkan bahwa ada hubungan yang positif antara ektrakurikuler seni kaligrafi dengan bakat seni rupa siswa MI miftahul Huda Tanjunganom Diwek Jombang. Hal ini dapat dibuktikan berdasarkan hasil perhitungan uji korelasi antara variabel $X$ dan variabel $Y$ diperoleh nilai sig $0,046 \leq$ 0,05. kemudian $\mathrm{N}$ (jumlah data responden) adalah 12, dan dari $\mathrm{R}$ (koefisien korelasi) bernilai 0,366 , maka nilai ini menandakan adanya hubungan yang tinggi antara ekstrakurikuler seni kaligrafi dengan bakat seni rupa siswa. 


\section{DAFTAR PUSTAKA}

A.R, Sirojuddin. Cara mengajar kaligrafi, darul ulum press, 2009.

Asmani, Jamal Ma'mur. kiat Mengembangkan Bakat Anak Di Sekolah, Yogyakarta: DIVA Press, 2012.

Asrori, Muhammad. Psikologi remaja (perkembagan peserta didik), Jakarta: PT.Bumi aksara, 2009.

Fatimah, Enung. Psikologi perkembangan (perkembangan peserta didik), Bandung: Pustaka Setia, cetakan ke-3 2010.

I Made Satya Wintara, Pentingnya Peran Guru Dalam Pengembangan Minat, Bakat Dan Kreativitas Siswa Melalui Ekstrakurikuler, https://www.researchgate.net/pu blication article/315110215, UniversitasPendidikan Ganesha, diakses pada tanggal 10 Januari 2019.

Kurniawan, Faidillah \& Tri Hadi. Ekstrakurikuler Sebagai Wahana Pembentukan Karakter Siswa di lingkungan Pendidikan Sekolah. Id.DOAJ.org (Education journal), 15, 240-263 2010.

Muslih, Imam \& Jazilatul Maghfiroh. Pengaruh penggunaan media visual dan model pembelajaran cooperative jigsaw terhadap hasil belajar. Jurnal Alta'dib vol 7 no.1.

Nuha, Ulin. Ragam Metodologi \& Media Pembelajaran Bahasa Arab, Yogyakarta: Diva Press, 2016.

Sukardi. Metodologi Penelitian Pendidikan, Jakarta: PT Bumi Aksara, 2009.

Sunarto dan B.Agung H. Perkembangan peserta didik, Jakarta:Rineka Cipta, 2008.

Suryabrata, Sumadi. Psikologi pendidikan, Jakarta: Rajawali press, cetakan ke-21, 2014. 